\title{
EFFECT OF PREHARVEST SPRAYING WITH THIDIAZURON ON FRUIT QUALITY AND MATURITY OF APPLES ${ }^{1}$
}

\author{
CASSANDRO VIDAL TALAMINI DO AMARANTE ${ }^{2}$, CLARICE APARECIDA MEGGUER ${ }^{3}$, LUIZ EDUARDO BASSAY \\ BLUM $^{4}$
}

\begin{abstract}
Apple trees, cultivars Gala and Fuji, were sprayed at full bloom with thidiazuron (TDZ) at the doses of 0, 5, 10, or 20 g (a.i.) ha-1 and fruit were assessed for quality and maturity. In both cultivars, the increase of TDZ dose had detrimental effects on fruit quality, causing a reduction of fruit red surface and an increase of percentage of fruit that was asymmetrical and with calyx-end rot. TDZ caused an increment of calyx-end aperture that might have increased calyx-end rot. TDZ increased density and the length : diameter (L : D) ratio of the fruit. The number of viable seeds was not affected by TDZ. TDZ resulted in a substantial delay of fruit maturity in 'Gala' but not in 'Fuji'. TDZ also reduced soluble solids content (SSC) in 'Gala' and reduced titratable acidity in both cultivars.
\end{abstract}

Index terms: Malus domestica Borkh., cytokinin, diphenylurea, skin color, fruit shape, calyx-end rot.

\section{EFEITOS DA PULVERIZAÇÃO PRÉ-COLHEITA COM THIDIAZURON SOBRE A QUALIDADE E A MATURAÇÃO DE FRUTOS EM MACIEIRAS}

RESUMO - Macieiras, cultivares Gala e Fuji, foram pulverizadas em plena floração com thidiazuron (TDZ), nas doses de 0; 5; 10 e 20 g (i.a.) ha-1 ${ }^{-1}$ e os frutos avaliados em termos de qualidade e maturação. Em ambas as cultivares, o TDZ apresentou efeitos negativos na qualidade dos frutos, com redução na percentagem de cor vermelha na casca e aumento na percentagem de frutos assimétricos e com podridão carpelar. O TDZ causou aumento na abertura carpelar, o que pode ter ocasionado aumento de incidência de podridão carpelar. O TDZ aumentou a densidade e a relação comprimento : diâmetro $(\mathrm{C}: \mathrm{D})$ dos frutos. O número de sementes viáveis não foi afetado pelo TDZ. O TDZ retardou substancialmente a maturação dos frutos na cultivar Gala, mas não na cultivar Fuji. O TDZ reduziu os teores de sólidos solúveis totais na cultivar Gala e reduziu a acidez titulável em ambas as cultivares.

Termos para indexação: Malus domestica Borkh., citocinina, difenil uréia, cor da casca, formato do fruto, podridão carpelar.

\section{INTRODUCTION}

The cytokinins are plant growth regulators with the ability to enhance plant cell division and cell expansion, as well as delay senescence (Taiz \& Zeiger, 1998). Recently, interest has been shown regarding the use of substituted phenylurea compounds, with cytokinin-like activity in plant tissues, to improve fruit set and fruit growth in temperate fruit trees (Elfving \& Cline, 1993; Famiani et al., 1999; Greene, 1995). Two synthetic substituted phenylureas, CPPU [N-(2-chloro-4-pyridyl)-N'phenylurea] and thidiazuron (TDZ; N-phenyl-N'-1,2,3-thiadiazol-5ylurea), show strong fruit growth promoting effect in apple, kiwifruit, grape, persimmon, and cucumber (Cruz Castillos et al., 1993; Elfving \& Cline, 1993; Famiani et al., 1999; Greene, 1995; Itai et al., 1995; Iwahori et al., 1988; Reynolds et al., 1992; Schuck \& Petri, 1992; Yang et al., 1992).

TDZ promotes fruit growth but it might alter fruit shape. The chemical reduced the fruit length : diameter $(\mathrm{L}: \mathrm{D})$ ratio in cucumber (Yang et al., 1992) and kiwifruit (Famiani et al., 1999), increased it in apple (Greene, 1995), but had no effect in persimmon (Itai et al., 1995). Increases in TDZ concentration and treatments closer to the full bloom increased the number of asymmetrical fruit in apple (Greene, 1995) and the number of fruit with distal protuberance in kiwifruit (Famiani et al., 1999; Schuck \& Petri, 1992).

Treatments with TDZ might affect fruit maturity and ripening. In persimmon, TDZ $\left(100 \mathrm{mg} \mathrm{L}^{-1}\right)$ sprayed at full bloom delayed fruit maturity. Fruit from TDZ treatment had higher flesh firmness, greener skin, and a lower glucose, fructose and total sugar content at harvest than the controls (Itai et al., 1995). In seedless grape, the immersion of berries (5-6 mm in diameter) in a solution of TDZ at doses up to $10 \mathrm{mg} \mathrm{L}^{-1}$ reduced anthocynins, ${ }^{\circ} \mathrm{Brix}$, and juice $\mathrm{pH}$, and increased juice titratable acidity of the fruit at harvest (Reynolds et al., 1992). In some cultivars, TDZ in- creased fruit weight loss and delayed the increase in ${ }^{\circ} \mathrm{Brix}$ and $\mathrm{pH}$ and the reduction of titratable acidity of fruit during storage. On the other hand, kiwifruit immersed in a solution of TDZ at dose of $20 \mathrm{mg} \mathrm{L}^{-1}$ fourteen days after full bloom had advanced maturity, with lower flesh firmness, lower titratable acidity and lower starch content, higher content of soluble sugars (glucose, fructose and sucrose), and higher ${ }^{\circ}$ Brix at harvest than untreated fruit (Famiani et al., 1999). Similar results were reported by Iwahori et al. (1988) in kiwifruit treated with CPPU. In 'McIntosh' apples, TDZ at doses between 10 and $50 \mathrm{mg} \mathrm{L}^{-1}$ increased flesh firmness at harvest when sprayed 22 days after full bloom but not when it was sprayed at full bloom (Greene, 1995). In 'Double Red Delicious' apples, TDZ sprayed at full bloom, at doses between 5 and $10 \mathrm{mg} \mathrm{L}^{-1}$, increased flesh firmness at harvest and after 26 weeks of regular storage. In 'Empire' apples, TDZ sprayed near the full bloom at doses up to $15 \mathrm{mg} \mathrm{L}^{-1}$ slightly increased flesh firmness and soluble solids concentration of the fruit at harvest.

This work was conducted to evaluate the effects of different doses of TDZ, sprayed at full bloom, on fruit attributes of quality and maturity of 'Gala' and 'Fuji' apples.

\section{MATERIALS AND METHODS}

The study was conducted in a commercial orchard in Lages, Santa Catarina State, Southern Brazil. Ten-year-old apple trees, cultivars Gala and Fuji, grafted on 'Marubakaido' rootstock, were sprayed at full bloom, in 1999, with TDZ at the doses of 0, 5, 10, or $20 \mathrm{~g}$ (a.i.) ha ${ }^{-1}$, with a total spray volume of $1,000 \mathrm{~L} \mathrm{ha}^{-1}$. The trees were treated with a tractormounted airblast sprayer. Spray barriers, made of polyethylene mounted on wood poles, were used to prevent spray drift between experimental plots. The experiment followed a completely randomized block design with four replicates. Each experimental unity was composed by five rows

\footnotetext{
${ }^{1}$ (Trabalho 079/2002). Recebido: 07/05/2002; Aceito para publicação: 07/02/2003

${ }^{2}$ Ph.D., Centro de Ciências Agroveterinárias (CAV), Universidade do Estado de Santa Catarina (UDESC), Cx. Postal 281, CEP 88502-970, Lages, SC, Brasil.E-mail: amarante@cav.udesc.br.

${ }^{3}$ Estudante do Curso de Agronomia, Centro de Ciências Agroveterinárias (CAV), Universidade do Estado de Santa Catarina (UDESC), Cx. Postal 281, CEP 88502-970, Lages, SC, Brasil. Bolsista de Iniciação Científica do CNPq.

${ }^{4}$ Ph.D., Centro de Ciências Agroveterinárias (CAV), Universidade do Estado de Santa Catarina (UDESC), Cx. Postal 281, CEP 88502-970, Lages, SC, Brasil.E-mail: a2lbb@cav.udesc.br.
} 
of eight plants. Only four plants in the center of the middle row had the fruit harvested. All fruit on two tagged limbs per plant were harvested at commercial maturity, selected for count 110-135 and assessed for quality and maturity.

Samples of 20 fruit per replicate were assessed for maturity at the commercial harvest, in terms of skin background color, flesh firmness, soluble solids content $\left({ }^{\circ} \mathrm{Brix}\right)$, starch pattern index, and titratable acidity. Skin background color was assessed by means of a color chart provided by ENZA New Zealand International on a scale of 1 (darkgreen) to 8 (yellow-green). Flesh firmness $(N)$ was determined on two sides of each fruit using a hand held penetrometer (Effegi FT 327, fitted with an $11.1 \mathrm{~mm}$ diameter head). Soluble solids content ( ${ }^{\circ} \mathrm{Brix}$ ) was determined with a hand refractometer on a composite juice sample collected during the pressure test. The starch pattern index (using the starch iodine test) was scored on a scale of 1 to 5 , where 1 indicates the least and 6 the most starch to sugar conversion. Titratable acidity ( $\%$ of malic acid) from juice composite samples of five fruits was determined by titrating to an end point of $\mathrm{pH} 8.2$ with $0.1 \mathrm{~N} \mathrm{NaOH}$. Samples of 20 fruit per replicate were assessed for skin permeance to water vapor as described by Amarante et al. (2001). Another lot of 30 fruit per replicate was sampled, the length : diameter $(\mathrm{L}: \mathrm{D})$ ratio and calyx-end aperture were measured (with a caliper), fruit red surface was estimated subjectively, fruit density $\left(\mathrm{kg} \mathrm{m}^{-3}\right.$; determined by the water displacement method) and asymmetry were assessed, and viable seeds counted.
Lots of 100 fruit per replicate of 'Gala' and 'Fuji' were cold stored $\left(0.5^{\circ} \mathrm{C}\right.$ and $\left.90-95 \% \mathrm{RH}\right)$ for 4.5 and 6.0 months, respectively, and assessed for calyx-end rot, internal ring-cracking, stem-end splitting and bitter pit ten days after removal from cold storage (shelf life at $10-15^{\circ} \mathrm{C}$ and $60-70 \% \mathrm{RH})$.

All data were subjected to statistical analysis using SAS (1990). Percentage data were transformed to arc $\sin [(x+5) / 100]^{1 / 2}$ before being submitted to the ANOVA. The effect of TDZ dose on each attribute assessed was analyzed by orthogonal polynomial contrasts.

\section{RESULTS AND DISCUSSION}

Fruit density was increased by TDZ in both cultivars (Table 1). TDZ by its cytokinin-like effect in promoting cells division and elongation at initial fruit development phase might reduce the intercellular space and thus increase fruit density of apples (Antognozzi et al., 1997; Famiani et al., 1999). This might increase fresh resistance to gases resulting in a larger depletion of $\mathrm{O}_{2}$ and/or accumulation of $\mathrm{CO}_{2}$ in the fruit internal atmosphere. 'Fuji' is highly susceptible to internal disorders induced by high levels of $\mathrm{CO}_{2}$ when this gas accumulates in the core region of fruit flesh at early stages of CA/MA storage (Argenta et al., 2000). Therefore, care should be taken with 'Fuji' apples if trees have been treated with TDZ to avoid stressful internal $\mathrm{CO}_{2}$ accumulation in the fruit under $\mathrm{CA} /$ MA storage that might render it susceptible to internal disorder.

TABLE 1- Fruit quality at the commercial harvest (mean \pm SE) of 'Gala' and 'Fuji' apples from trees sprayed with different doses of thidiazuron (TDZ) at full bloom. The significance of linear and quadratic relationships between doses of TDZ and fruit quality attributes were analyzed by means of polynomial orthogonal contrasts $(*, * *$ and $* * *$ for 5,1 , and $0.1 \%$ of significance, respectively; ns: non significant).

\begin{tabular}{|c|c|c|c|c|c|c|c|}
\hline $\begin{array}{l}\text { TDZ } \\
\left(\mathrm{g} \mathrm{ha}^{-1}\right)\end{array}$ & $\begin{array}{l}\text { Fruit density } \\
\left(\mathrm{kg} \mathrm{m}^{-3}\right)\end{array}$ & Surface red $(\%)$ & $\begin{array}{l}\text { Calyx-end aperture } \\
(\mathrm{mm})\end{array}$ & $\begin{array}{c}\text { Calyx-end rot } \\
(\%)\end{array}$ & $\begin{array}{l}\text { Asymmetrical fruit } \\
(\%)\end{array}$ & $\begin{array}{l}\mathrm{L}: \mathrm{D} \\
\text { ratio }\end{array}$ & Seeds/ fruit \\
\hline 0 & $0.855 \pm 0.001$ & $53.0 \pm 2.3$ & $5.4 \pm 0.1$ & $0.0 \pm 0.0$ & $4.2 \pm 2.5$ & $0.910 \pm 0.005$ & $6.1 \pm 0.2$ \\
\hline 10 & $0.854 \pm 0.001$ & $54.6 \pm 2.3$ & $5.8^{ \pm} 0.1$ & $0.8 \pm 0.8$ & $53.3 \pm 3.6$ & $0.926 \pm 0.004$ & $6.0 \pm 0.2$ \\
\hline 20 & $0.859 \pm 0.001$ & $44.8 \pm 2.3$ & $6.8 \pm 0.1$ & $4.2 \pm 1.6$ & $56.7 \pm 8.5$ & $0.925 \pm 0.004$ & $5.9 \pm 0.2$ \\
\hline Linear & $* *$ & $*$ & $* * *$ & $*$ & $* * *$ & $*$ & ns \\
\hline 0 & $0.852 \pm 0.002$ & $46.3 \pm 2.1$ & $5.0 \pm 0.1$ & $29.2 \pm 1.6$ & $34.2 \pm 4.4$ & $0.853 \pm 0.005$ & $7.2 \pm 0.2$ \\
\hline 5 & $0.856 \pm 0.002$ & $39.6 \pm 1.8$ & $5.2 \pm 0.1$ & $35.0 \pm 5.5$ & $55.0 \pm 6.2$ & $0.853 \pm 0.005$ & $7.3 \pm 0.2$ \\
\hline 10 & $0.858 \pm 0.001$ & $39.3 \pm 2.2$ & $5.3 \pm 0.1$ & $41.5 \pm 7.8$ & $55.8 \pm 2.8$ & $0.868 \pm 0.007$ & $7.1 \pm 0.2$ \\
\hline 20 & $0.860 \pm 0.002$ & $37.7 \pm 1.8$ & $5.3 \pm 0.1$ & $41.7 \pm 5.5$ & $55.0 \pm 6.4$ & $0.872 \pm 0.006$ & $7.3 \pm 0.2$ \\
\hline Linear & $* * *$ & $* *$ & $*$ & $*$ & $*$ & $* *$ & ns \\
\hline Quadratic & $\mathrm{ns}$ & ns & ns & ns & $*$ & ns & ns \\
\hline
\end{tabular}

TDZ reduced the color development in the skin (Table 1). In both cultivars, the dose of $20 \mathrm{~g} \mathrm{ha}^{-1}$ reduced the percentage of fruit surface that was red in about $10 \%$. This confirms results of Greene (1995), who reported reduced red color of apples from trees sprayed near the full bloom with TDZ and CPPU at concentrations of 10 and $20 \mathrm{mg} \mathrm{L}^{-1}$. Also, on seedless grapes, TDZ reduced the juice anthocyanin content (Reynolds et al., 1992). This might have been the result of TDZ delaying fruit maturity (therefore delaying anthocyanins synthesis) or by some direct effect of TDZ on metabolic pathways leading to anthocyanins synthesis in the fruit skin. Nevertheless, the reduced red color of fruit skin at harvest caused by TDZ has a substantial negative impact on apples quality.

TDZ increased the calyx-end aperture in both cultivars, and this might have contributed to increase the incidence of calyx-end rot (Table 1). TDZ sprayed at full bloom on apple trees reduced fruit calcium content (Amarante et al., 2002) and this might have also increased fruit susceptibility to calyx-end rot infection during fruit growth on the tree. Apples with low calcium content are more susceptible to decay (Conway et al., 1999). The higher incidence of ca- lyx-end rot in 'Fuji' than in 'Gala' might reflect differences in susceptibility to fungal infection and/or the differences of fruit harvesting dates between these cultivars. 'Fuji' is harvested latter than 'Gala' and, therefore, exposed to a longer period of fungal infection before harvest that might increase the incidence of calyx-end rot. In recent years, the increasing concern of apple growers in Southern Brazil with the high losses caused by calyx-end rot might reflect the intensive used of TDZ to improve fruit set.

TDZ had a substantial effect on apples shape, resulting in fruit that was asymmetrical and with a high $\mathrm{L}$ : D ratio (Table 1). TDZ, by its cytokinin-like effect, affects the direction of cell division or cell expansion resulting in more elongated apples (Elfving \& Cline, 1993; Greene, 1995). The malformation in fruits treated with phenylureas seems to be the result of extremely limited mobility and redistribution of the product from the application sites, causing uneven fruit growth and misshapen (Biasi et al., 1993). In 'Gala', the percentage of asymmetrical fruit was $4 \%$ for the control treatment and higher that $50 \%$ for TDZ at doses of 10 and $20 \mathrm{~g} \mathrm{ha}^{-1}$ (Table 1). In 'Fuji', the percentage of asymmetrical fruit was about $30 \%$ for the 
control treatment and increased to about $55 \%$ for TDZ at doses higher than $5 \mathrm{~g} \mathrm{ha}^{-1}$ (Table 1). In apple, Greene (1995) observed fruit malformation with increases of TDZ concentration specially when treatments were made latter after full bloom (18 days after full bloom). In kiwifruit, high doses of TDZ increased the number of fruit with distal protuberance (Famiani et al., 1999; Schuck \& Petri, 1992). The asymmetry may be overcome by more uniform distribution over the fruit surface, using uniform application of small droplets or multiple sprays at low concentration of TDZ (Biasi et al., 1993), and by avoiding treatments later after full bloom (Greene, 1995).

The number of viable seeds per fruit was not affected by TDZ in both cultivars (Table 1). In kiwifruit, the number of seeds per fruit was not affected by treatments with TDZ at doses of $20 \mathrm{mg} \mathrm{L}^{-1}$ (Famiani et al., 1999). In 'Double Red Delicious' apples, TDZ did not affect seed count when tree were sprayed at full bloom with doses of 5 or $10 \mathrm{mg} \mathrm{L}^{-1}$ (Greene, 1995). However, in 'Empire' apples, TDZ sprayed 22 days after full bloom to promote fruit thinning, at doses of 62 or $125 \mathrm{mg} \mathrm{L}^{-1}$, nearly eliminated seed development (Elfving \& Cline, 1993). Nevertheless, the reduced seed count did not influence fruit shape, fruit size and fruit-fresh nutrient concentration $(\mathrm{N}, \mathrm{P}, \mathrm{K}, \mathrm{Ca}$, and $\mathrm{Mg}$ ). At doses of 10 or $50 \mathrm{mg} \mathrm{L}^{-1}$, TDZ reduced seed count in 'McIntosh' apples when the product was sprayed at full bloom or 22 days after full bloom; the highest concentration and latter application caused the greatest reduction of seed count (Greene, 1995). In the present study, the lack of effect of TDZ on seed count might reflect the use of small doses of the product (doses up to $20 \mathrm{~g} \mathrm{ha}^{-1}$, corresponding to $\sim 20 \mathrm{mg} \mathrm{L}^{-1}$ ), and its application at full bloom. This might also indicate that 'Gala' and 'Fuji' are less prone to seed abortion by TDZ. In addition, since the experimental area had high presence of honeybees, and the weather conditions were favorable for the entomophilic pollination, this might have prevented any effect of TDZ on seed count.

Fruit maturity was strongly delayed by TDZ in 'Gala' (an early harvested cultivar) but not in 'Fuji' (a late harvested cultivar) (Table 2). In 'Gala', TDZ increased the green color of the skin, soluble solids content, starch pattern index, and titratable acidity, while flesh firmness was not affected (Table 2). In 'Fuji', TDZ increased the soluble solids content and reduced titratable acidity, while flesh firmness, starch patter index and skin background color were not affected (Table 2). This indicates that on early picked apple cultivars (such as 'Gala') TDZ has a more substantial effect to delay fruit maturity. This delay is expected since compounds with cytokinin-like activity are known to slow senescence, of which fruit ripening is a specialized form (Taiz \& Zeiger, 1998). TDZ and CPPU also delayed fruit maturity in grape, persimmon and apple (Greene, 1995; Itai et al., 1995; Reynolds et al., 1992). However, in kiwifruit, TDZ and CPPU induced early ripening by increasing soluble solid content and reducing the total titratable acids and flesh firmness (Antognozzi et al., 1997; Famiani et al., 1999; Iwahori et al., 1988). This represents a relevant difference with respect to the action of this compound in other fruits. According to Famiani et al. (1999), there are no biochemical data to explain the effect of TDZ and CPPU on kiwifruit ripening.

TABLE 2- Fruit maturity at the commercial harvest (mean \pm SE) of 'Gala' and 'Fuji' apples from trees sprayed with different doses of thidiazuron (TDZ) at full bloom. The significance of linear and quadratic relationships between doses of TDZ and fruit maturity attributes were analyzed by means of polynomial orthogonal contrasts $(*, * *$ and $* * *$ for 5,1 , and $0.1 \%$ of significance, respectively; ns: non significant).

\begin{tabular}{|c|c|c|c|c|c|}
\hline $\begin{array}{c}\text { TDZ } \\
\left(\mathrm{g} \mathrm{ha}^{-1}\right)\end{array}$ & Skin background color & $\begin{array}{c}\text { Firmness } \\
(\mathrm{N})\end{array}$ & $\begin{array}{c}\text { Soluble solids content } \\
\left({ }^{\circ} \text { Brix }\right)\end{array}$ & Starch index ${ }^{(2)}$ & Titratable acidity (\%) \\
\hline & \multicolumn{5}{|c|}{ GALA } \\
\hline 0 & $4.5 \pm 0.1$ & $82.8 \pm 0.7$ & $11.9 \pm 0.1$ & $3.4 \pm 0.1$ & $0.342 \pm 0.013$ \\
\hline 5 & $4.4 \pm 0.1$ & $84.1 \pm 0.7$ & $11.7 \pm 0.1$ & $3.0 \pm 0.1$ & $0.342 \pm 0.013$ \\
\hline 10 & $4.5 \pm 0.1$ & $80.3 \pm 0.5$ & $11.5 \pm 0.1$ & $3.5 \pm 0.1$ & $0.308 \pm 0.007$ \\
\hline 20 & $3.9 \pm 0.1$ & $82.4 \pm 0.6$ & $11.1 \pm 0.1$ & $2.9 \pm 0.1$ & $0.268 \pm 0.007$ \\
\hline Linear & $* * *$ & ns & $* * *$ & $*$ & $* * *$ \\
\hline Quadratic & $*$ & ns & $\mathrm{ns}$ & ns & $\mathrm{ns}$ \\
\hline & \multicolumn{5}{|c|}{ FUJI } \\
\hline 0 & $4.0 \pm 0.1$ & $71.9 \pm 0.5$ & $13.1 \pm 0.1$ & $4.3 \pm 0.04$ & $0.315 \pm 0.007$ \\
\hline 5 & $4.0 \pm 0.1$ & $71.7 \pm 0.5$ & $13.1 \pm 0.1$ & $4.1 \pm 0.04$ & $0.335 \pm 0.007$ \\
\hline 10 & $4.1 \pm 0.1$ & $72.3 \pm 0.5$ & $13.5 \pm 0.1$ & $4.2 \pm 0.04$ & $0.315 \pm 0.007$ \\
\hline 20 & $4.1 \pm 0.1$ & $72.9 \pm 0.5$ & $13.5 \pm 0.2$ & $4.3 \pm 0.04$ & $0.295 \pm 0.007$ \\
\hline Linear & ns & ns & $* *$ & ns & $* *$ \\
\hline Quadratic & ns & ns & ns & $*$ & $*$ \\
\hline
\end{tabular}

(1) On a scale of 1 (dark green) to 8 (yellow-green).

(2) On a scale of 1 to 5 , where 1 indicate the least and 5 the most starch to sugar conversion.

Fruit sensory quality of apples at harvest was adversely affected by TDZ in both cultivars, by its effect in reducing soluble solids content and titratable acidity in 'Gala', and by reducing titratable acidity in 'Fuji' (Table 2). Similar results of TDZ were reported for grape and persimmon (Itai et al., 1995; Reynolds et al., 1992). The product also tended to increase average weight loss per cluster of grapes during storage (Reynolds et al., 1992). However, our results did not show any effect of TDZ on skin permeance to water and weigh loss of apples. Despite of the effects of TDZ in reducing fruit calcium content in apples (Amarante et al., 2001), the product did not affect the incidence of calcium deficiency disorders, such as internal ring-cracking, stem-end splitting, and bitter pit. This might be the result of very high calcium levels in the fruit for all treatments in 1999/2000.

\section{CONCLUSIONS}

1) TDZ sprayed at full bloom to promote fruit set has detrimental effects on fruit quality of apples by reducing the fruit red surface and increasing the percentage of fruit that was asymmetrical and with calyx-end rot;

2) TDZ substantially delays fruit maturity on 'Gala' but not on 'Fuji' apples;

3) TDZ adversely affects fruit postharvest sensory quality of apples by reducing soluble solids content and titratable acidity in 'Gala', and by reducing titratable acidity in 'Fuji'. 


\section{ACKNOWLEDGMENTS}

The authors are grateful to Yakult S.A. and Agrícola Fraiburgo S.A. for their support in conducting the field works, and to the Brazilian Association of Apple Growers (ABPM) for the grant that partially supported this research.

\section{REFERENCES}

AMARANTE, C.; BANKS, N.H.; GANESH, S. Relationship between character of skin cover of coated pears and permeance to water vapour and gases. Postharvest Biology and Technology, Amsterdam, v. 21, n. 3, p. 291-301, 2001.

AMARANTE, C.V.T.; ERNANI, P.R.; BLUM, L.E.B.; MEGGUER, C. A. Thidiazuron affects fruit set, return bloom, shoot growth, and nutrition of apples. Pesquisa Agropecuária Brasileira, Brasília, 2002. (no prelo)

ANTOGNOZZI, E.L.; FAMIANI, F.; FERRANTI, F.; FRENGUELLI, G.; PROIETTI, P.; TOMBESI, A. Effect of CPPU (cytokinin) treatments on fruit anatomical structure and quality in Actinidia deliciosa. Acta Horticulturae, Wageningen, n. 444, p. 459-465, 1997.

ARGENTA, L.; FAN, X.; MATTHEIS, J. Delaying establishment of controlled atmosphere or $\mathrm{CO}_{2}$ exposure reduces 'Fuji' apple $\mathrm{CO}_{2}$ injury without excessive fruit quality loss. Postharvest Biology and Technology, Amsterdam, v. 20, n. 3, p. 221-229, 2000.

BIASI, R.; NERI, D.; SUGIYAMA, N.; COSTA, G. ${ }^{14} \mathrm{C}-\mathrm{CCPU}$ uptake and distribution in developing kiwifruits and apples. Acta Horticulturae, Wageningen, n. 329, p. 101-104, 1993.

CONWAY, W.S.; JANISIEWICZ, W.J.; KLEIN, J.D.; SAMS, C.E. Strategy for combining heat treatment, calcium infiltration, and biological control to reduce postharvest decay of 'Gala' apples. HortScience, Alexandria, v. 34, n. 4, p. 700-704, 1999.

CRUZ CASTILLO, J.C.; WOOLLEY, D.J.; LAWES, G.S. The effects of seeds and the application of a growth regulator mixture, on fruit growth in 'Hayward' kiwifruit. Acta Horticulturae, Wageningen, n. 444, p. 459-465, 1993.

ELFVING, D.C.; CLINE, R.A. Cytokinin and ethephon affects crop load, shoot growth, and nutrient concentration of 'Empire' apple trees. HortScience, Alexandria, v. 28, n. 6, p. 1011-1014, 1993.

FAMIANI, F.; BATTISTELLI, A.; MOSCATELLO, S.; BOCO, M.; ANTOGNOZZI, E. Thidiazuron affects growth, ripening and quality of Actinidia deliciosa. Journal of Horticultural Science \& Biotechnology, Kent, v. 74, n. 3, p. 375-380, 1999.

GREENE, D.W. Thidiazuron effects on fruit set, fruit quality, and return bloom of apples. HortScience, Alexandria, v. 30, n. 6, p. 12381240, 1995.

ITAI, A.; TANABE, K.; TAMURA, F.; SUSAKI, S.; YONEMORI, K.; SUGIURA, A. Synthetic cytokinins control persimmon fruit shape, size and quality. Journal of Horticultural Science, Kent, v. 70, n. 6, p. 867-873, 1995.

IWAHORI, S.; TOMINAGA, S.; YAMASAKI, T. Stimulation of fruit growth of kiwifruit, Actinidia chinensis Planch., by N-(2-chloro4-pyridyl)-N'-phenylurea, a diphenylurea derivative cytokinin. Scientia Horticulturae, Amsterdam, v. 35, n. 1-2, p. 109-115, 1988. REYNOLDS, A.G.; WARDLE, D. A.; ZUROWSKI, C.; LOONEY, N. E. Phenylureas CPPU and thidiazuron affects yield components, fruit composition, and storage potential of four seedless grape selections. Journal of the American Society for Horticultural Science, Alexandria, v. 117, n. 1, p. 85-89, 1992.

SAS. Cary: SAS institute, 1990.789 p.

SCHUCK, E.; PETRI, J.L. Efeitos do thidiazuron no peso médio dos frutos de quivi. Revista Brasileira de Fruticultura, Cruz das Almas, v. 14, n. 2, p. 185-188, 1992.

TAIZ, L.; ZEIGER, E. Plant physiology. 2 ed. Sunderland: Sinauer Associates, Publishers, 1998. 793 p.

YANG, Y-Z.; LIN, D-C; GUO, Z-Y. Promotion of fruit development in cucumber (Cucumis sativus) by thidiazuron. Scientia Horticulturae, Amsterdam, v. 50, n. 1-2, p. 47-51, 1992. 